\title{
Pendekatan Continuous Improvement Penurunan Donwntime Pada Sistem Pengisian Air Minum Gallon
}

\author{
Dwi Wiyono $^{1}$, Ellysa Nursanti ${ }^{2}$, Thomas Priyasmanu ${ }^{3}$ \\ 1, Mahasiswa Teknik Industri S-1 ITN Malang \\ ${ }^{2}$ Program Studi Teknik Industris ${ }^{\mathrm{S}-2}$, Pascasarjana, ITN Malang \\ ${ }^{3}$ Program Studi Teknik Industri ${ }^{\mathrm{S}-1}$, FTI, ITN Malang \\ *Email: dwibaru13@gmail.com
}

\begin{abstract}
Abstrak
Permasalahan yang terjadi di PT. Tirta Investama adalah adanya tingginya jumlah downtime di line 5 gallon area gattot kaca. Downtime terjadi dikarenakan botol sering menyangkut dan belum ada standarisasi pemasangan pocket holder. Oleh sebab itu, dilakukan penelitian guna menurunkan jumlah downtime dengan menggunakan metode Continuous Improvement (CI). Penelitian menggunakan metode Continuous Improvement (CI), melalui tahapan Plan-Do-Check-Act (PDCA). Plan dilakukan untuk mengetahui permasalahan kondisi nyata di lapangan. Setelah itu, mengidentifikasi penyebabpenyebab masalah yang terjadi. Kemudian Do dilakukan untuk memberi saran usulan standarisasi kepada perusahaan. Check dilakukan dengan menyusun intruksi kerja yang digunakan untuk mengetahui standarisasi dilakukan dengan baik pada perusahaan. Action digunakan untuk mengetahui perkembangan setelah ada perbaikan. Setelah semua tahap penelitian dilakukan dan implementasi PDCA, maka dapat disimpulkan bahwa jumlah downtime menurun dari 6176,96 menit menjadi 16,52 diatasi dengan standarisasi peralatan dan proses, standarisasi pemasangan komponen, dan standarisasi tenaga kerja. Selain itu, intruksi kerja yang diusulkan, berhasil menurunkan jumlah downtime dan membuat proses produksi menjadi lebih baik.
\end{abstract}

Kata kunci: Downtime, Standarisasi, Continuous Improvement

\section{Pendahuluan}

Sebuah industri manufaktur dengan continuous improvement sangat erat kaitannya dengan 3 faktor yaitu performance, quality dan availability. Ketiga faktor ini harus selalu dijaga dan perlu diperhatikan dalam tujuan mencapai sistem yang efektif dan efisien. Availability rate suatu sistem produksi merupakan salah satu hal penting yang perlu dicermati, karena availability rate adalah salah satu tolak ukur tingkat keefektifan proses produksi dan memiliki hubungan langsung dengan komponen sistem, misalnya mesin. Availability rate sangat erat kaitannya dengan downtime. Downtime adalah total waktu saat unit mengalami kerusakan/kegagalan dimulai dari waktu kerusakan terjadi hingga waktu set-up ulang unit. Saat sebuah unit mengalami kerusakan, unit tersebut sudah memasuki waktu proses perbaikan. Tingginya frekuensi downtime loss dalam suatu sistem, akan menyebabkan availability rate yang rendah dan berdampak pada laju produksi yang turun sehingga kapasitas produksi tidak optimal [1].

Sistem proses produksi di PT. Tirta Investama masih belum optimal, disebabkan sistem masih sering berhenti ditunjukkan dengan angka downtime selama 3 bulan yaitu pada bulan Oktober sebesar 698.55 menit, November sebesar 986.41 dan pada bulan Desember sebesar 1404.10 menit. Dimana permasalahan ini akan menyebabkan kerugian yang sangat besar bila tidak dilakukan perbaikan. Angka downtime yang tinggi ini terjadi karena seringnya botol nyangkut di mesin fiiller. 
Jurnal Teknologi dan Manajemen Industri, Vol. 4 No. 1, Februari 2018

Pascasarjana Institut Teknologi Nasional Malang

Tabel 1. Data downtime selama 3 bulan

\begin{tabular}{|l|l|c|c|c|c|c|c|}
\hline \multirow{2}{*}{ NO } & \multirow{2}{*}{ Indikator } & \multicolumn{2}{|c|}{ Oktober 2016 } & \multicolumn{2}{c|}{ November 2016 } & \multicolumn{2}{c|}{ Desember 2016 } \\
\cline { 3 - 8 } & Durasi & Frekwensi & Durasi & Frekwensi & Durasi & Frekwensi \\
\hline 1 & $\begin{array}{l}\text { Downtime } \\
\text { (menit) }\end{array}$ & 698.55 & 28 & 986.41 & 163 & 1404 & 136 \\
\hline
\end{tabular}

Sumber: PT Tirta Investama Pandaan

Pada Tabel 1 Terlihat bahwa dengan jumlah selama 3 bulan jika dijumlahkan yaitu sebesar 3088.96 menit dan 1 menit mesin dapat memproduksi 4 botol maka, bila dikonversikan kedalam rupiah dapat mencapai kerugian sebesar Rp.308.848.000 selama 3 bulan. Hasil produksi menyebabkan produk tidak dapat bersaing global. Hal ini jika terjadi secara terus menerus, maka industri tersebut tidak dapat bersaing dengan kompetitornya. Untuk jangka panjang, usaha tersebut bisa merugi.

Tujuan dari penelitian ini adalah untuk menurunkan downtime guna menstabilkan proses produksi sehingga dapat meningkatkan produktivitas, untuk itu perlu dilakukan upaya-upaya penurunan downtime,salah satunya adalah melalui penerapan PDCA. PDCA atau (Plan, Do, Check, Action) adalah sebuah siklus perbaikan yang merupakan adaptasi dari metode ilmiah [2].

Mengacu pada penurunan downtime, banyak peneliti terdahulu yang telah meneliti dan mendiskusikan topik ini,namun para peneliti hanya meneliti satu siklus saja. Sedangkan untuk yang sekarang peneliti akan menggunakan siklus berkelanjutan dimana akan terjadi perbaikan dan pemeliharaan secara berkelanjutan.

\section{Metodologi Penelitian}

Metode yang digunakan pada penelitian ini adalah Continuous Improvement yang dicapai dengan tahap Plan-Do-Check-Act (PDCA).seperti dibawah ini:

1. Plan

Pada tahap Plan merupakan perencanaan dengan mencari permasalahan kondisi di lapangan yang terjadi dan mengidentifikasi penyebab-penyebab yang mungkin timbul dengan menggunakan end state analysis.

\section{Do}

Tahap do adalah tahap penerapan atau melaksanakan semua yang telah direncanakan di tahap plan. Setelah mengidentifikasi penyebab-penyebab pada tahap plan menggunakan diagram End State Analysis, dapat dibuat perencanaan perbaikan pada proses pengisian air gallon. Supaya mendapatkan hasil yang stabil, maka pada proses perencanaan perbaikan yang perlu dilakukan pada line 5 gallon area Gatot kaca PT. Tirta Investama adalah Menetapkan usulan intruksi kerja untuk Pemasangan Setting Pocket Holder,yang kemudian akan digunakan untuk tahap check dan action..

\section{Check}

Tahap check adalah tahap pemeriksaan dan peninjauan ulang serta mempelajari hasil-hasil dari penerapan di tahap do dengan melakukan inspeksi setelah perbaikan untuk menjaga konsistensi tingkat keberhasilan dalam melaksanakan sesuatu pekerjaan tertentu. Selain itu, sebagai acuan dalam pelaksanaan kegiatan tertentu sesama pekerja.

\section{Action}

Tahap action adalah tahap untuk mengambil tindakan terhadap hasil-hasil dari tahap check dengan membuat Action Plan Analisa yang digunakan untuk mengetahui hasil setelah dilakukan perbaikan setelah menerapkan intruksi kerja. 

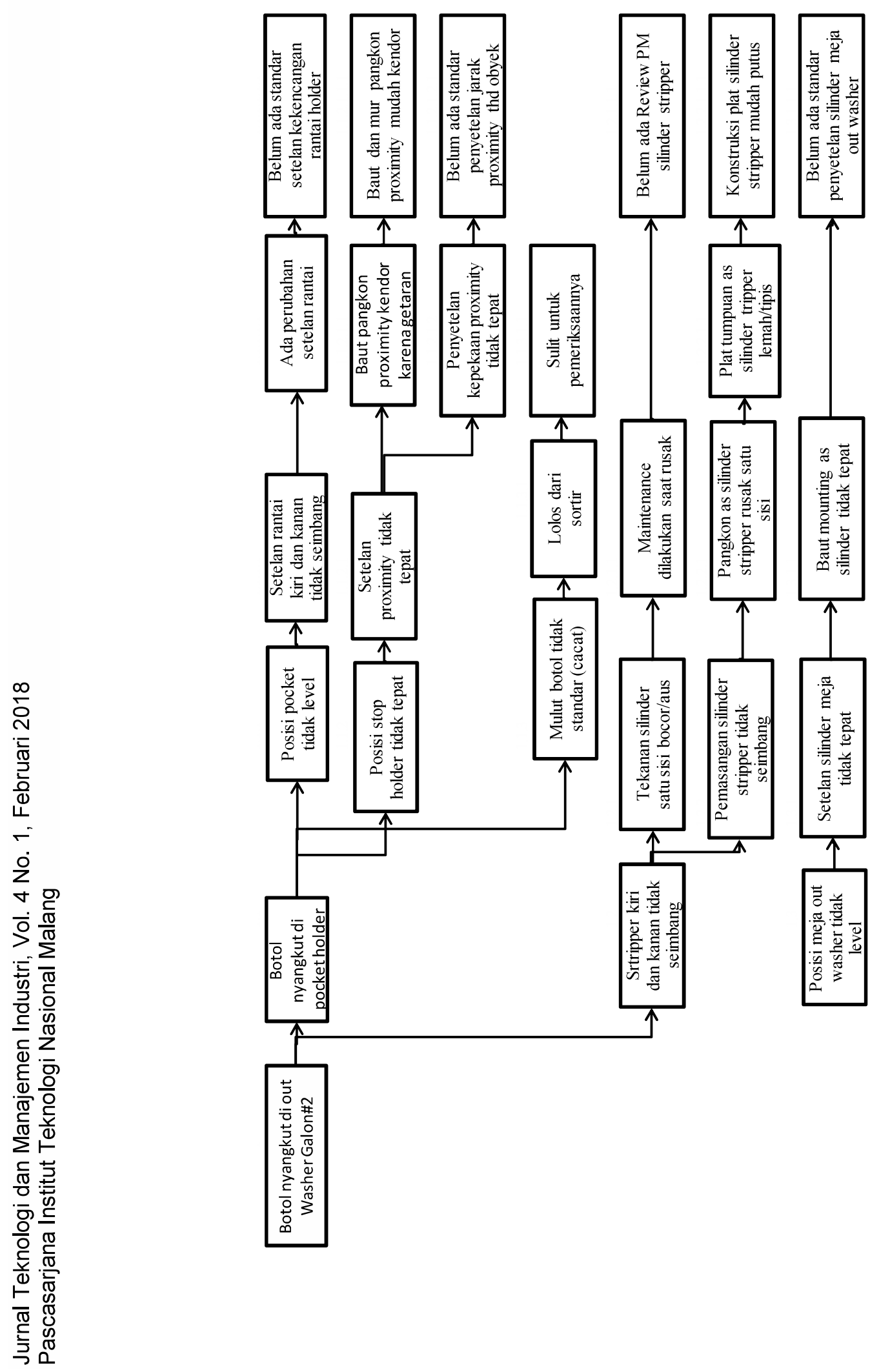

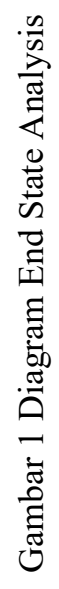


Berdasarkan gambar 1 diagram End State Analysis di atas, dapat dibuat perencanaan perbaikan pada proses pengisian air gallon. Supaya mendapatkan hasil yang stabil, maka pada proses perencanaan perbaikan yang perlu dilakukan pada line 5 gallon area Gatot kaca PT. Tirta Investama adalah Menetapkan intruksi kerja.

\section{Standarisasi}

Standarisasi adalah menetapkan, menerapkan dan merevisi standar, yang dilaksanakan secara tertib melalui kerjasama dengan semua pihak yang terlibat dalam usaha industri.

Analisis Usulan Standarisasi

Sesuai hasil penelitian bahwa pada proses perbaikan mesin di PT. Tirta Investama belum memiliki standard perbaikan pada setiap mesin, standar tenaga kerja, standar peralatan maupun proses, dan standar lingkungan. Mengingat tidak ada standar pada proses, penulis memberikan solusi perbaikan dengan pembuatan standarisasi pada proses yang belum ada ketetapan, sehingga proses produksi dapat berjalan lebih optimal. Berdasarkan perencanaan yang telah disusun, pelaksanaan yang perlu dilakukan ialah pengusulan standarisasi pada proses. Dibawah ini merupakan gambar usulan Pemasangan Setting Pocket Holder.

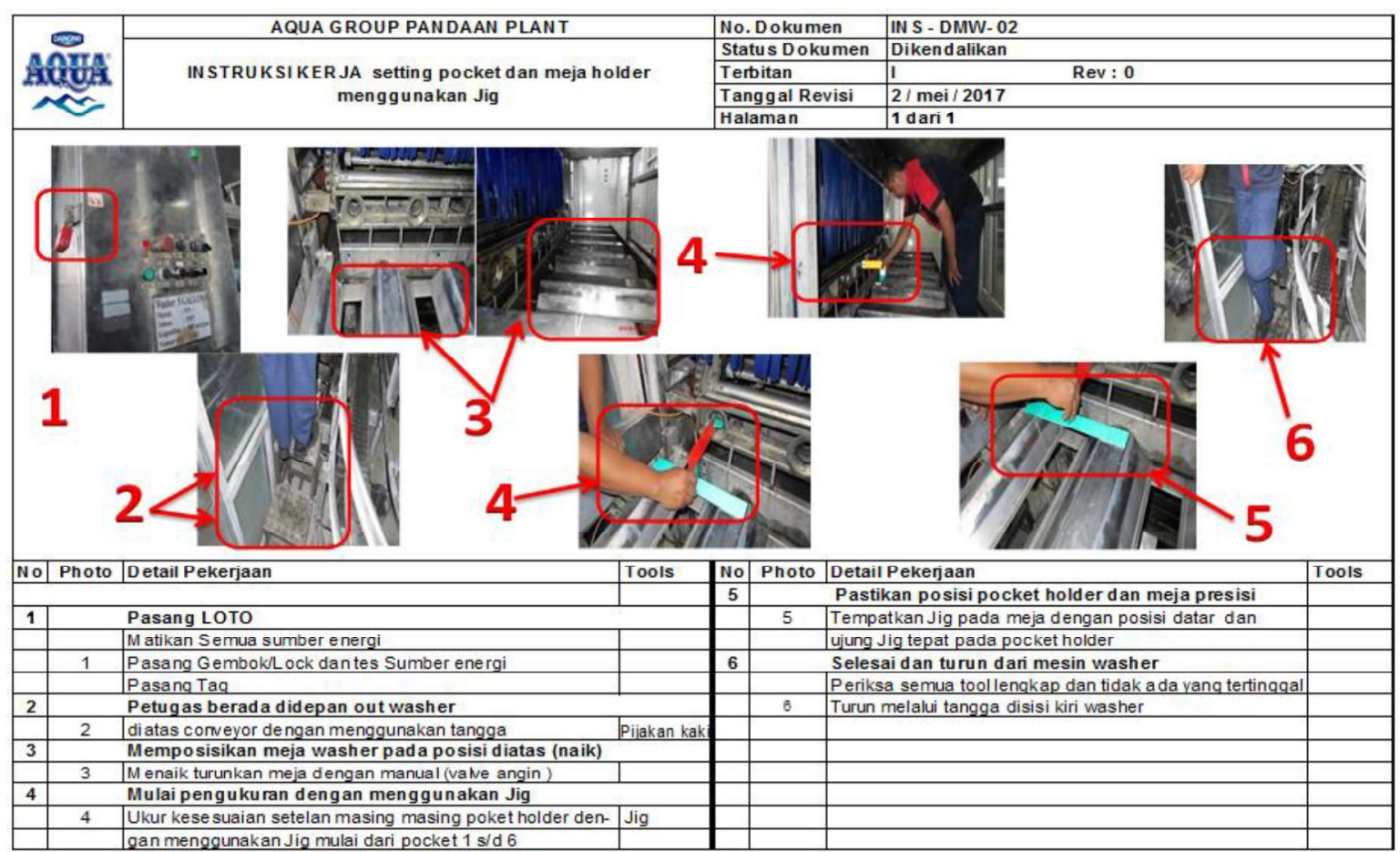

Gambar 2. Intruksi Kerja Pemasangan Setting Pocket Holder

Sumber: PT Tirta Investama Pandaan 
Jurnal Teknologi dan Manajemen Industri, Vol. 0 No. 0, Agustus 2018

Pascasarjana Institut Teknologi Nasional Malang

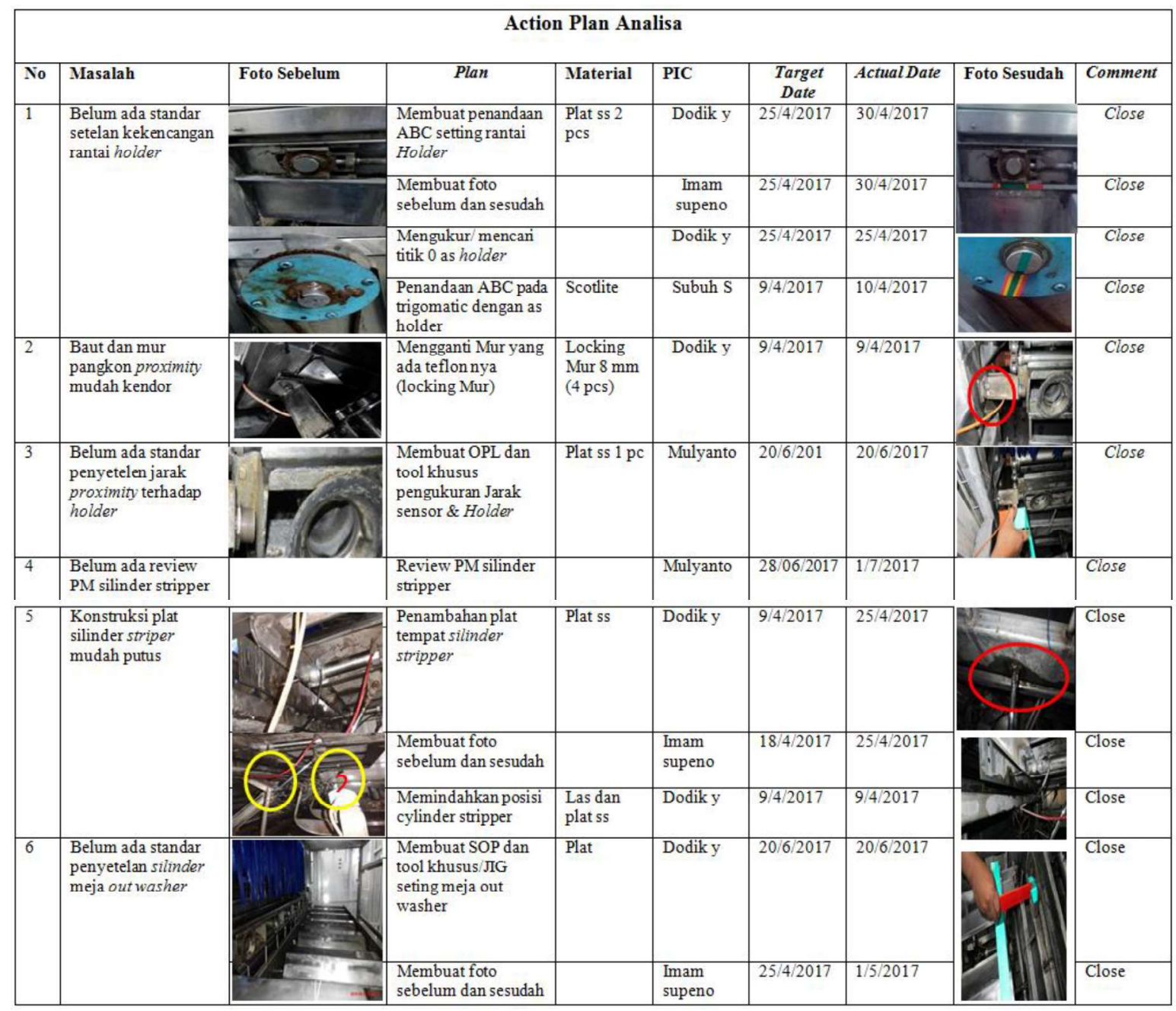

Gambar 3.Action Plan Analisa

Sumber: PT Tirta Investama Pandaan

Gambar 3. Action Plan analisa merupakan penjelasan dari tahap Plan-Do-Check- and Action. Plan merupakan perencanaan perbaikan yang akan dilakukan untuk menyelesaikan permasalahan seperti yang terlihat pada kolom plan, kemudian tahap senjutnya, do adalah penyediakan material yang di butuhkan dan melaksanakan semua yang telah direncanakan, kemudian melakukan pemeriksaan dan peninjauan ulang serta mempelajari hasil-hasil dari penerapan di tahap do dengan melakukan inspeksi setelah perbaikan seperti yang terlihat pada foto sebelum dan sesudah perbaikan pada gambar 4. dan terakhir langkah tindak lanjut (action) adalah tahap untuk mengambil tindakan terhadap hasil-hasil dari tahap check seperti yang terlihat pada kolom comment dan berisi keterangan close jika permasalah dapat diselesaikan.

\section{Hasil}

Setelah melakukan analisis proses, sebelum dan sesudah adanya standarisasi, berikut dapat dilihat perbandingannya pada Tabel 2 . 
Jurnal Teknologi dan Manajemen Industri, Vol. 0 No. 0, Agustus 2018

Pascasarjana Institut Teknologi Nasional Malang

Tabel 2. Analisis Sebelum Perbaikan dan Sesudah Perbaikan

\begin{tabular}{|c|l|l|}
\hline No. & \multicolumn{1}{|c|}{ Sebelum perbaikan } & \multicolumn{1}{c|}{ Sesudah Perbaikan } \\
\hline 1 & $\begin{array}{l}\text { Belum ada standar setelan } \\
\text { kekencangan rantai holder }\end{array}$ & $\begin{array}{l}\text { Sudah ada standar setelan kekencangan } \\
\text { rantai holder }\end{array}$ \\
\hline 2 & $\begin{array}{l}\text { Baut dan mur pangkon proximity } \\
\text { mudah kendor }\end{array}$ & $\begin{array}{l}\text { Baut dan mur pangkon } \text { proximity } \\
\text { tidak mudah kendor }\end{array}$ \\
\hline 3 & $\begin{array}{l}\text { Belum ada standar penyetelan jarak } \\
\text { proximity terhadap holder }\end{array}$ & $\begin{array}{l}\text { Sudah ada standar penyetelan jarak } \\
\text { proximity terhadap holder }\end{array}$ \\
\hline 4 & Belum ada review PM silinder stripper & Sudah ada review PM silinder stripper \\
\hline 5 & $\begin{array}{l}\text { Konstruksi plat cylinder striper mudah } \\
\text { putus }\end{array}$ & $\begin{array}{l}\text { Konstruksi plat } \text { cylinder striper tidak } \\
\text { mudah putus }\end{array}$ \\
\hline 6 & $\begin{array}{l}\text { Belum ada standar penyetelan silinder } \\
\text { meja } \text { out } \text { washer }\end{array}$ & $\begin{array}{l}\text { Sudah ada standar penyetelan silinder } \\
\text { meja } \text { out } \text { washer }\end{array}$ \\
\hline
\end{tabular}

Setelah melakukan perbaikan jumlah downtime untuk bulan Januari sampai April mengalami penurunan seperti yang terlihat pada tabel 2 di bawah ini:

Tabel 2. Analisis hasil Data Downtime Perusahaan Sebelum Perbaikan dan Sesudah Perbaikan

\begin{tabular}{|c|c|c|c|}
\hline \multicolumn{3}{|c|}{ Sebelum perbaikan } & Sesudah Perbaikan \\
\hline \multicolumn{2}{|c|}{ R2-Botol Menyangkut di out washer } & $\begin{array}{c}\text { R2-Botol Menyangkut } \\
\text { di out washer }\end{array}$ \\
\hline $\begin{array}{c}\text { Priode } \\
\text { (bulan) }\end{array}$ & $\begin{array}{c}\text { Durasi } \\
\text { Downtime } \\
\text { (MENIT) }\end{array}$ & $\begin{array}{c}\text { Priode } \\
\text { (bulan) }\end{array}$ & $\begin{array}{c}\text { Durasi Downtime } \\
\text { (MENIT) }\end{array}$ \\
\hline Oktober & 698.55 & Januari & 24.2 \\
\hline November & 986.41 & Febuari & 22.4 \\
\hline Desember & 1404 & Maret & 90.78 \\
\hline- & - & April & 25.14 \\
\hline Total & 6176.96 & Total & 162.52 \\
\hline \multicolumn{3}{|c|}{ Sumber: PT Tirta Investama Pandaan } \\
\hline
\end{tabular}

\section{Kesimpulan}

Berdasarkan permasalahan pada penelitian ini yaitu tingginya jumlah downtime, maka dapat dilakukan perbaikan dengan siklus PDCA yang dapat menjamin suatu perbaikan yang berkesinambungan. Untuk memperoleh suatu perbaikan pada permasalahan ini, maka penelitian ini mengusulkan standarisasi pada kondisi di lapangan, yaitu standarisasi pemasangan pocket holder. Setelah adanya suatu perbaikan di perusahaan. ini didapatkan hasil yang lebih baik, sehingga output produksi menjadi lebih baik.Tingginya downtime dapat diturunkan dari 6.176 .96 menit menjadi 162.52 menit,setara dengan 0,97\% dengan menggunakan metode Continuous Improvement

\section{Daftar Referensi}

[1] Ebeling, An Introduction to Reliability and Maintainability Engineering, New York: McGraw Hill, 1997. 
Jurnal Teknologi dan Manajemen Industri, Vol. 0 No. 0, Agustus 2018

Pascasarjana Institut Teknologi Nasional Malang

[2] Rohana,S dan Widyo,S. 2012. Analisis penyebab keterlambatan pekerjaan mekanikal umum pada proyek network building dengan pendekatan kualitatif metode PDCA: Jurnal Teknik FTUP, vol. 25, no.2 